\title{
Using road pricing as a viable option to meet Australia's future road funding needs
}

Brendan Lyon

Australia faces two problems in road transportation: on the supply side, we face diminishing revenues to maintain and expand the road network; and, on the demand side, we lack any effective tools to manage congestion or shape peak demand periods.

Together, these factors see lower capital, productive and allocative efficiency in road transport-hence our rapidly escalating economic and social costs. Various reports by the Productivity Commission, the Bureau of Infrastructure, Transport and Regional Economics (BITRE), Infrastructure Australia, Infrastructure Partnerships Australia and others outline these challenges.

In this chapter, I will discuss where we can act to address these essential transport challenges, what this might mean for the road network and users and what it (ideally) means for those who are working in policy roles with the government-and why you should be enthusiastic and actively involved in this issue. 


\section{Everything old is new again}

User charges through both public tolls and even identifiable early forerunners of modern road public-private partnerships (PPPs) have been used from the earliest days of colonial Australia.

The first toll way, a bridge, opened in 1802, just 14 years after the First Fleet made landfall and almost a century before Federation (New South Wales Parliament Legislative Council 2017). Indeed, by the later nineteenth century, colonial Sydney had numerous tolling plazas, with tolls levied to fund the expansion and maintenance of the road network.

Modern road PPPs also have recognisable precedent in colonial times. The original Pyrmont Bridge in Sydney is one such example. Opening in 1858 , the bridge was privately developed and financed, with colonial legislation granting a right to the owners to levy a differential toll on users-essentially the same as a modern PPP.

This relatively long history of tolls and charges involved community issues similar to those in modern times. Figure 7.1 is an excerpt from an 1863 letter to the Sydney Morning Herald by Mr John Pendrill, complaining about aspects of the Pyrmont Bridge charge. I note that Mr Pendrill continued to use the bridge-because it was convenient.

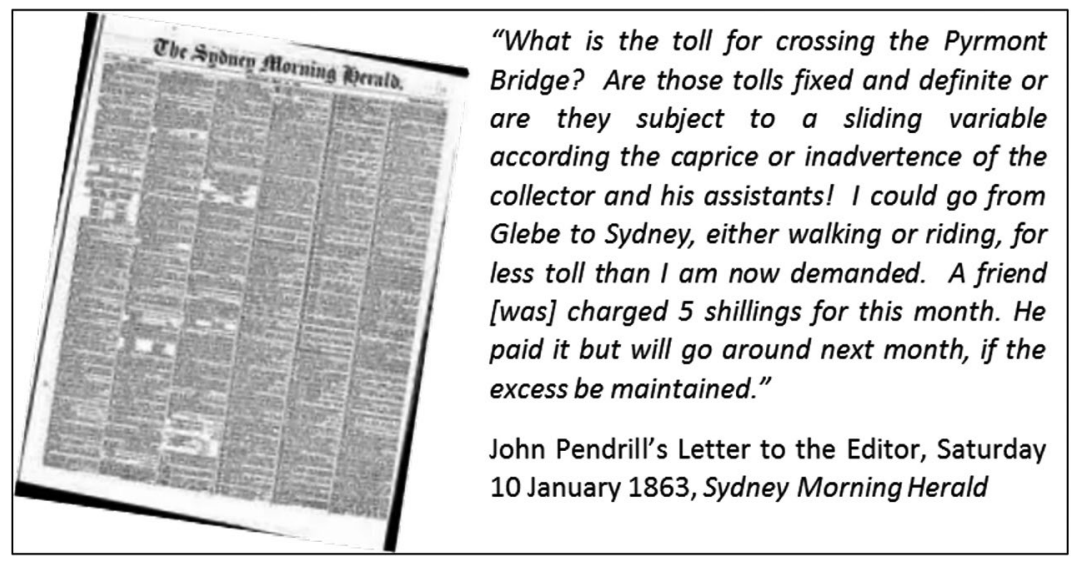

Figure 7.1 Variable tolling in 1863

Source: Sydney Morning Herald, 10 January 1863. 
Pendrill's letter reflects two points that remain true today. First, while people will never love paying for access, they will pay where it provides value. This relates to Alex Robson's point (Chapter 6, this volume) about choosing the right assets, with the right capacity and in the right places. The second point is that opposition to user charging is not new; it has always been and remains a sharp aspect of the infrastructure debate.

\section{From road tolls to road pricing}

Beyond individual 'facility' tollways, a wider concept of whole-network road user models has a much shorter history. The Industry Commission (now Productivity Commission) developed road pricing concepts in its Rail Transport report (Industry Commission 1991).

While that report principally considered the operational structure of public sector railways, it also developed a case for rationalised, costreflective transport pricing across the wider transport network, across modes and across different journey types. This work shows the very high level of policy sophistication in the Industry Commission at that time, given that enabling technologies such as the Global Positioning System (GPS) and even free-flow tolling based on radio-frequency identification (RFID) were yet to come into existence.

\section{Revenue decay creates a burning platform for change}

Our analysis of contemporary transport infrastructure funding sources showed substantial decay in the Commonwealth fuel excise, with the earlier de-indexation of the fuel tax and a consumer shift towards fuel-efficient vehicles combining to halve federal fuel excise revenues as a proportion of receipts.

Infrastructure Partnerships Australia released its first volume of work on the structure of Australia's road transport market in early 2010, reflecting our view that structural change in some form was unavoidable because of this debased revenue model. Reflecting the Industry Commission's (much) earlier work, our paper developed concepts for a system where the 
road-related taxes and charges become a fundamental response to improve the productive, allocative and dynamic efficiency challenges affecting Australia's transport system.

Ultimately, our paper resolved the abolition of the current federal/state 'fuel tax plus rego' two-part tariff in favour of a much more sophisticated and equitable pricing model, with charges calculated on:

- the distance travelled

- vehicle mass

- the location of use

- the time of day.

This is an economically efficient but radically different model to what we are used to-a pricing model that allows costs of use, including congestion, to be made explicit to the user rather than absorbed by the community at large.

\section{Road pricing and funding reform principles}

Noting the potential for (sometimes extreme) community and political sensitivity to major reform options, we released our 2010 paper to develop key concepts, but also to provide a basis for discussion of the issue with policymakers and, particularly, with the major motoring clubs.

This was deliberate because, practically, road pricing would be unlikely to receive any degree of policy consideration if the key user groups opposed it.

In what is an enduring credit to Australia's motoring clubs, far from being opposed to change, they were highly engaged and highly knowledgeable. Brian Negus from the Royal Automobile Club of Victoria (RACV) and then CEO of the Australian Automobile Association (AAA) Andrew McKellar deserve particular credit for their willingness to engage and to lead on this issue — as does Michael Bradley, the current AAA CEO.

By 2014, our partnership with the motoring clubs saw us jointly release a major study called Road Pricing and Transport Infrastructure Funding: Reform pathways for Australia (Infrastructure Partnerships Australia 2014). It is available on the Infrastructure Partnerships Australia website and is an interesting piece of work. 
This paper addressed important questions, particularly around how rationalised pricing might affect typical users-for example, people in regional areas.

In this way, it allowed the motoring clubs to adopt a position on this difficult issue - and, in so doing, to signal to policymakers they were up for a process of serious structural change.

While we have not published on this yet, the revenue hypothecation aspect of our reformed pricing model should be supported by complementary measures to enhance the dynamic efficiency of road transport, through adopting utility-type regulation of capital investments and operating expenditures. This could inform user price setting, but also simultaneously take road transport legitimately 'off budget' and remove it from political or geographic bias in capital expenditures.

\section{The four fundamental problems in Australia's contemporary road transport sector}

Our 2014 paper identified four fundamental problems:

1. The revenue model is fundamentally debased.

2. There is an opaque connection between revenue collection and network investment.

3. There is a lack of sophistication in the two-part tariff pricing model (as also noted by Alex Robson in this volume).

4. The current pricing model sees inequitable outcomes for user groups.

We resolved that, for these fundamental reasons, the current system is not sustainable in the longer term without change.

\section{The terminal revenue model}

Figure 7.2 shows the terminal decay of the Commonwealth fuel excise, which, by $2010-11$, had almost halved in proportional terms. This has been led by two factors. First, the biannual indexation of fuel excise to the consumer price index (CPI) was abolished in 2001 and not reintroduced until 2014-15. The second, continuing and now accelerating factor is the community's shift to fuel-efficient, hybrid and 'fuel-free' electric vehicles. 


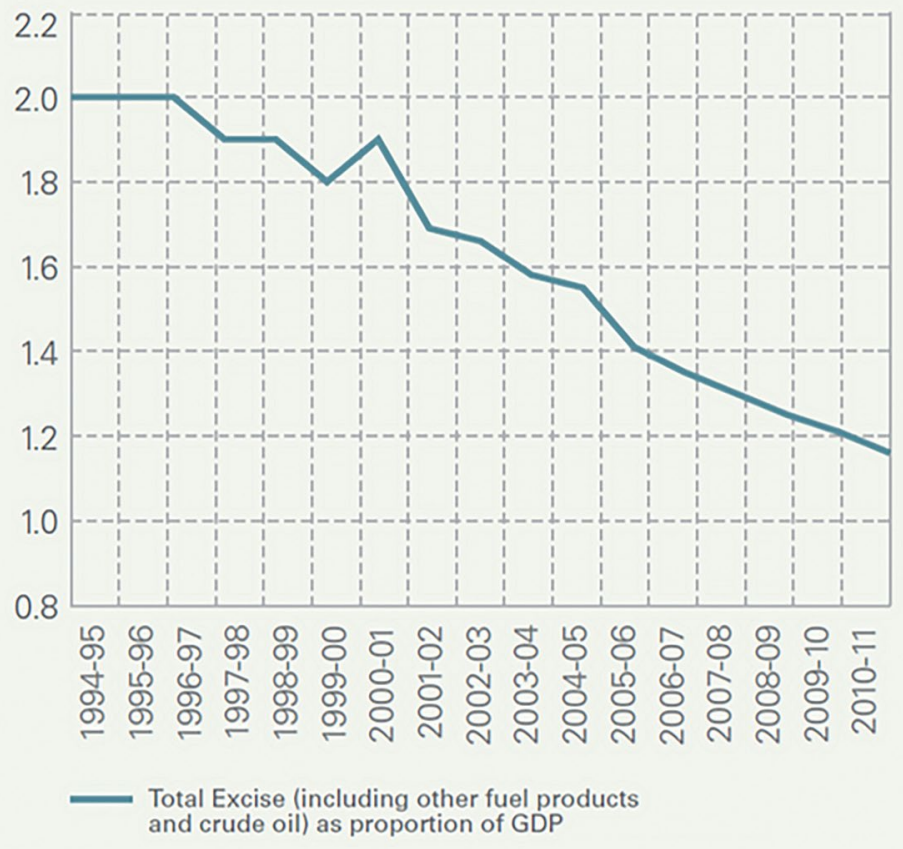

Figure 7.2 Fuel excise as a proportion of gross domestic product (GDP) Source: Infrastructure Partnerships Australia (2014).

\section{It's opaque}

A key benefit of structural change is the opportunity to fundamentally connect what users are charged with what funds are expended-and on what. The current system has developed organically over a century or so, with predictably confused structures and a resulting lack of transparency and accountability. Figure 7.3 describes the status quo.

A key aspect of our model is the hypothecation of road-related taxes and charges to transport - thereby insulating motorists from subsidising consolidated revenue-and insulating state treasuries from subsidising motorists.

Hypothecation would allow the revenue collection envelope to be calculated, based on determination of allowed levels of capital investment, and transparency and review of the cost to motorists from the operation and maintenance of the wider road network. 


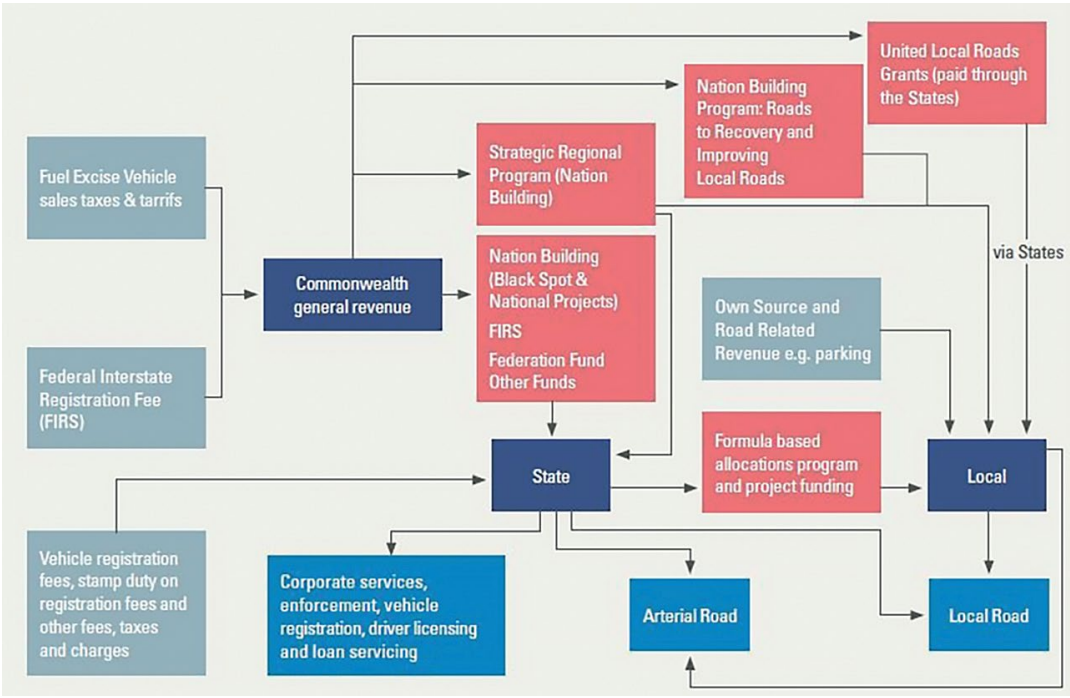

Figure 7.3 There is no link between revenue and investment

Source: Infrastructure Partnerships Australia (2014).

\section{It's unsophisticated}

While the fuel excise was designed to price road consumption, it cannot make fuel consumed in peak hour in Melbourne or Sydney more expensive than fuel consumed on, for example, a regional road. This means the road pricing model lacks the sophistication to manage urban congestion-the most obvious, the most frustrating and the most costly transport challenge.

Australia's road network is available 24 hours a day; it endures excessive demand during the relatively short commuter and weekend peaks in major cities, but it also sees massive underutilisation during other periods, particularly overnight. There is a practical limit to the number of new lanes that can be built on motorways, meaning that some form of demand management will be needed in key areas.

Congestion could be resolved through the type of cordon or area charging schemes considered and assessed in our paper (and discussed by Alex Robson in Chapter 6); but in our work we found that this would neglect the important opportunities to increase the overall performance of road transport. 
The Productivity Commission has recently produced two reports on the pricing and funding of roads that attempted to resolve such important transport issues. The first report, chaired by Gary Banks in 2006, attempted to calculate the actual costs of road and rail freight infrastructure, with a view to introducing user charging for heavy road usage. It also attempted to calculate the costs of congestion. The second report, in 2015, chaired by Peter Harris, looked more broadly at user charging and optimal models for road funding and reflects the concepts in Infrastructure Partnerships Australia's work on the topic. This second report contained two important recommendations (DIRD 2014: 11):

\section{Recommendation 8.1}

The first step in a long-term transition to a more efficient and effective approach to the provision and funding of roads should be the establishment of Road Funds by State and Territory Governments. State Governments, and local government associations, should actively encourage and support local governments to form regional Road Funds for networks of local roads. To be effective, Road Funds should:

- have the objective of clearly linking road-user preferences with investment and maintenance decisions

- integrate the tasks of road funding and provision

- have a significant degree of autonomy

- have access to adequate revenue to meet the costs of the road network they administer, as required by the relevant road users

- entail transparent processes for determining the level and allocation of funds

- include an open and transparent procedure for direct involvement of road users and consultation with the broader community on project selection, funding, and road charging decisions

- involve systematic post-project evaluation and periodic review of the arrangements.

The implementation of Road Funds should take into account the research and analysis developed for heavy vehicles by the Heavy Vehicle Charging and Investment reform project ...

\section{Recommendation 4.1}

The Australian Government should actively encourage State and Territory Governments to undertake pilot studies on how vehicle telematics could be used for distance and location charging of cars and other light vehicles. To do so, the Australian Government should: 
- offer to partly fund these pilot studies

- work with the States and Territories to address privacy concerns and share lessons from the trials and overseas experience

- ensure that motorists are directly involved via roads and motorists associations.

The pilot studies should be designed to inform future consideration of a shift to direct road user charging for cars and other light vehicles, with the revenue hypothecated to roads. Heavy vehicle trials could also be developed on a similar basis. The Road Funds proposed in recommendation 8.1 could be tasked to undertake the trials if this does not result in unreasonable delay.

\section{What are we trying to achieve?}

Across policy work, Infrastructure Partnerships Australia emphasises the need to identify the fundamental outcomes sought through change.

In our 2014 paper on road pricing, we refined these 'first principles' into a simple assessment framework through which to analyse the spectrum of potential pricing models. We filtered these models against their ability to deliver:

- adequate revenue to sustainably fund transport network expansions such as new roads

- adequate revenue to fund appropriate maintenance

- a fairer allocation of costs and benefits in the transport market

- funding stream security

- improved network performance.

\section{It's nice to have options}

Cordon or area charging was the first model we assessed. The community is broadly familiar with these types of schemes, which operate, for example, in London, Stockholm, Milan and Singapore. Our assessment showed that while these are relatively simple to design and implement and observably effective in dealing with congestion, there are limitations to simply bolting on additional charges in particular areas. 
Table 7.1 Cordon area pricing assessment

\section{CAN CORDON/AREA PRICING}

Fund additions to the transport network

Fund network maintenance

Provide a fair allocation of costs

and benefits

Provide a secure funding stream

Provide the opportunity to improve

network performance

\section{CORDON/AREA PRICING}

= partially.

Source: Infrastructure Partnerships Australia (2014).

Next, we assessed a 'national highway improvement charge', a facility charge that would see revenue collected from, and reinvested in, particular roads, corridors or networks. This approach could allow the cost of particular roads or networks to be removed from government budgetssimilar to some European networks such as Italy's Autostrada. As with cordon charging, this type of approach was found to be too limited when compared with the breadth of challenges facing Australian transport.

Table 7.2 Highway improvement charge assessment

\begin{tabular}{l|l|}
\hline $\begin{array}{l}\text { CANA NATIONAL HIGHWAY } \\
\text { IMPROVEMENT CHARGE }\end{array}$ & $\begin{array}{l}\text { NATIONAL HIGHWAY } \\
\text { IMPROVEMENT CHARGE }\end{array}$ \\
\hline $\begin{array}{l}\text { Fund additions to the transport network } \\
\text { Fund network maintenance }\end{array}$ \\
\hline Provide a fair allocation of costs and benefits \\
\hline Provide a secure funding stream \\
\hline $\begin{array}{l}\text { Provide the opportunity to improve } \\
\text { network performance }\end{array}$ \\
\hline$=$ partially.
\end{tabular}

Source: Infrastructure Partnerships Australia (2014). 
Having rejected limited pricing models applying to all vehicles, but only on parts of the network, we next assessed a model that would apply to the whole network- but only to particular vehicles, such as freight vehicles. This kind of 'whole of network, partial fleet' pricing model offers substantial benefits in terms of a detailed trial for a broader road pricing reform, and could conceivably be progressively rolled out to cover additional vehicle classes. Logically, however, the full benefits of the pricing signals offered by a whole-of-network model would not be realised when only particular vehicles are covered, so the scheme only partially meets most of the objectives laid out for road pricing reform (see Table 7.3).

Table 7.3 Network pricing assessment

\section{CAN THE SELECTED VEHICLE CLASS(ES), \\ WHOLE-OF-NETWORK REGIME}

SELECTED VEHICLE CLASS(ES), WHOLEOF-NETWORK

\section{Fund additions to the transport network \\ Fund network maintenance \\ Provide a secure funding stream \\ Provide the opportunity to improve network performance \\ $=$ partially.}

Provide a fair allocation of costs and benefits

Source: Infrastructure Partnerships Australia (2014).

Logically, given the scale of misallocations, inefficiencies, cross-subsidies and revenue decay in road transport, we found that enduring solutions could only be found through fundamental, systemic change.

Our universal road user charging (URUC) model would cover all vehicles and the entire road network and see the existing 'fuel tax plus rego' charges abolished, replaced with on-vehicle charging based on the time, mass, distance and location of use.

As shown in Table 7.4, our URUC delivered the broadest range of benefits, but would represent the deepest and widest microeconomic reform in several decades—no mean feat in today's policy environment! 
ROAD PRICING AND PROVISION

Table 7.4 Assessment of universal road user charging model

\section{CAN UNIVERSAL ROAD USER CHARGING}

\section{UNIVERSAL ROAD} USER CHARGING (ALL VEHICLES WHOLE NETWORK)

Fund additions to the transport network

Fund network maintenance

Provide a fair allocation of costs and benefits

Provide a secure funding stream

Provide the opportunity to improve

network performance

Source: Infrastructure Partnerships Australia (2014).

Table 7.5 shows the simplified options analysis, with the existing framework of road user charging used as the base case for assessment.

Table 7.5 Comparison of options

\begin{tabular}{|c|c|c|c|c|c|c|}
\hline CHARGING REGIME & $\begin{array}{l}\text { EXISTING } \\
\text { FRAMEWORK }\end{array}$ & $\begin{array}{l}\text { CORDON/AREA } \\
\text { PRICING }\end{array}$ & $\begin{array}{l}\text { NATIONAL } \\
\text { HIGHWAY } \\
\text { IMPROVEMENT } \\
\text { CHARGE }\end{array}$ & $\begin{array}{l}\text { SELECTED } \\
\text { VEHICLE } \\
\text { CLASSIES), } \\
\text { PARTIAL } \\
\text { NETWORK }\end{array}$ & $\begin{array}{l}\text { SELECTED } \\
\text { VEEICLE } \\
\text { CLASSIES), } \\
\text { WHOLE-OF } \\
\text { NETWORK }\end{array}$ & $\begin{array}{l}\text { UNIVERSAL } \\
\text { ROAD USER } \\
\text { CHARGE } \\
\text { (ALL VEHICLES, } \\
\text { WHOLE } \\
\text { NETWORK) }\end{array}$ \\
\hline $\begin{array}{l}\text { Funding additions to the transport } \\
\text { network - can the charging regime } \\
\text { provide a sustainable funding mechanism } \\
\text { to provide capacity enhancements to } \\
\text { the transport network? }\end{array}$ & & & & & & \\
\hline $\begin{array}{l}\text { Funding network maintenance - can } \\
\text { the charging regime provide a secure } \\
\text { and reactive funding source for network } \\
\text { maintenance? }\end{array}$ & & & & & & \\
\hline $\begin{array}{l}\text { A fair allocation of costs and benefits } \\
\text { - can the charging regime ensure a fair } \\
\text { distribution of costs between users, } \\
\text { where those who use more, pay more } \\
\text { and those who use less, pay less? }\end{array}$ & & & & & & \\
\hline $\begin{array}{l}\text { Funding stream security - can the } \\
\text { charging regime offer a secure funding } \\
\text { stroam that roflocts changing demand } \\
\text { for road usage and promotes longer term } \\
\text { investment planning? }\end{array}$ & & & & & & \\
\hline $\begin{array}{l}\text { Improving network performance - can } \\
\text { the charging regime provide appropriate } \\
\text { pricing signals for road users and road } \\
\text { providers to improve the performance of } \\
\text { the network? }\end{array}$ & & & & & & \\
\hline
\end{tabular}

Source: Infrastructure Partnerships Australia (2014). 


\section{Impacts on users}

To allow a thorough assessment of the typical user price impacts that might be expected under the proposed URUC, we defined a number of 'test users'. The rationale for generating test users was to provide a sample of different types of light vehicle to compare and contrast the different components of the model and provide 'real-world' user comparisons against the existing charging regime. These test users are shown in Figure 7.4.

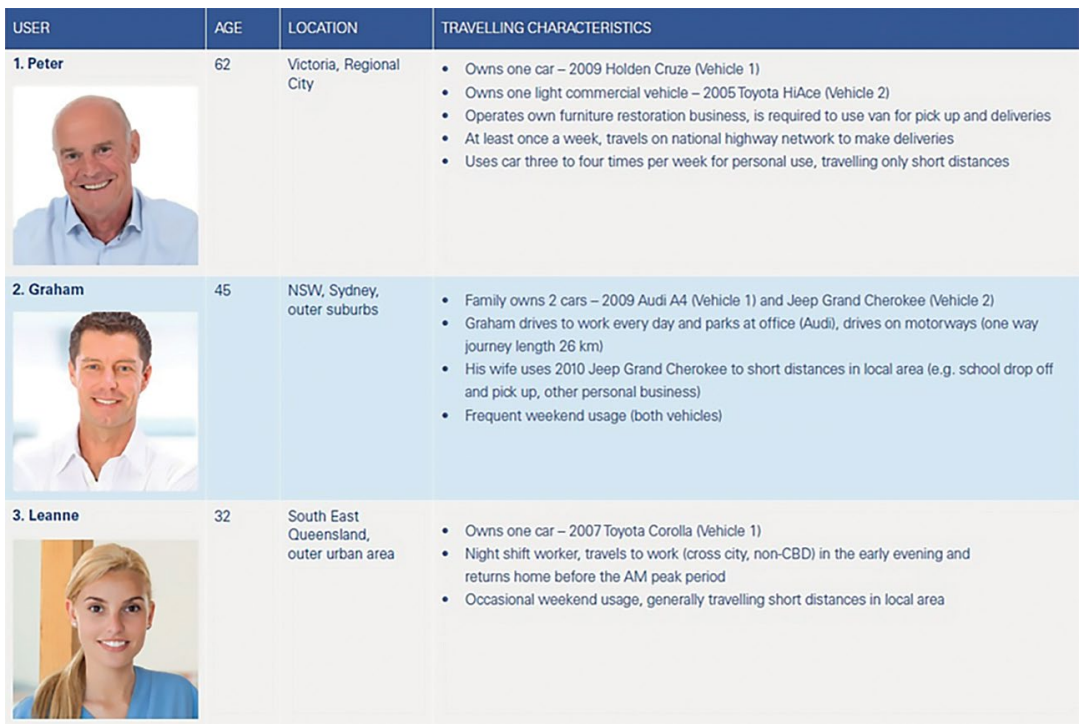

Figure 7.4 Avatars representing different road user profiles

Source: Infrastructure Partnerships Australia (2014).

Peter, the first avatar, owns a single vehicle, which he drives a few times a week for personal use on short trips, and a light commercial vehicle that he uses for his business. Under the URUC model we applied, he would pay 23 per cent less because he is a low mileage user outside the city. This is important, because one of the fears regional motorists have, by virtue of the long distances they need to travel, is that they might have to pay more. In fact, the model we applied shows there is a very large cross-subsidy that comes from capital city users and goes across to non-capital city users.

Graham, the second avatar, has two cars, an Audi A4 and a Jeep Cherokee. He drives to work every day along a highly utilised motorway corridor north-west of Sydney and his wife drives short distances in the local area-for example, for the school drop-off. We found for this household 
a roughly 10 per cent cost increase. For Graham, it is a 45 per cent increase, but there is a substantial decrease for his wife. Again, it shows that, across the household, the outcome is fairer.

Leanne, our third avatar, is a nurse from south-eastern Queensland. Leanne does not drive in the capital city and there is a large cross-subsidy that is flowing through from her road use, resulting in a 23 per cent reduction in her costs. Additionally, she does not travel during peak times.

Table 7.6 shows a comparison of the new charges estimated under the URUC model with charges under the current system. The structure put forward would see no greater cost burden on users as a whole; rather, it would redistribute charges to better reflect true costs (including externalities) and benefits. Before implementation of a similar scheme (or any reform to road user charging), detailed analysis of the price elasticity of demand will be required. However, if structured correctly and priced efficiently, a rational road user charging model would see appropriate and intended shifts in the demand profile.

Table 7.6 Estimate of new road use charges in 2012 dollars

\begin{tabular}{|c|c|c|c|c|c|c|}
\hline \multirow[t]{2}{*}{ USER } & \multirow[t]{2}{*}{ BASE CASE } & \multicolumn{3}{|c|}{ UNIVERSAL ROAD USER CHARGING } & \multirow{2}{*}{$\begin{array}{r}\text { TOTAL NEW } \\
\text { CHARGES }\end{array}$} & \multirow[t]{2}{*}{$\%$ CHANGE } \\
\hline & & BASE CHARGE & $\begin{array}{r}\text { DISTANCE ROAD } \\
\text { USE CHARGE }\end{array}$ & $\begin{array}{r}\text { TIME ROAD USE } \\
\text { CHARGE }\end{array}$ & & \\
\hline \multicolumn{7}{|l|}{ Peter } \\
\hline Vehicle One & $\$ 10.97$ & $\$ 0.96$ & $\$ 2.40$ & $\$ 0.00$ & $\$ 3.36$ & $-69.4 \%$ \\
\hline Vehicle Two & $\$ 38.07$ & $\$ 0.96$ & $\$ 33.53$ & $\$ 0.00$ & $\$ 34.49$ & $-9.4 \%$ \\
\hline Total & $\$ 49.04$ & $\$ 1.92$ & $\$ 35.93$ & $\$ 0.00$ & $\$ 37.85$ & $.22 .8 \%$ \\
\hline \multicolumn{7}{|l|}{ Graham } \\
\hline Vehicle One & $\$ 26.09$ & $\$ 0.96$ & $\$ 18.04$ & $\$ 18.94$ & $\$ 37.95$ & $45.4 \%$ \\
\hline Vehicle Two & $\$ 20.16$ & $\$ 0.96$ & $\$ 5.90$ & $\$ 6.07$ & $\$ 12.93$ & $-35.9 \%$ \\
\hline Total & $\$ 46.25$ & $\$ 1.92$ & $\$ 23.94$ & $\$ 25.01$ & $\$ 50.87$ & $10.0 \%$ \\
\hline \multicolumn{7}{|l|}{ Leanne } \\
\hline Vehicle One & $\$ 15.61$ & $\$ 0.96$ & $\$ 10.43$ & $\$ 0.57$ & $\$ 11.96$ & $-23,4 \%$ \\
\hline Vehicle Two & $\$ 0.00$ & $\$ 0.00$ & $\$ 0.00$ & $\$ 0.00$ & $\$ 0.00$ & \\
\hline Total & $\$ 15.61$ & $\$ 0.96$ & $\$ 10.43$ & $\$ 0.57$ & $\$ 11.96$ & $-23.4 \%$ \\
\hline
\end{tabular}

Source: Infrastructure Partnerships Australia (2014).

\section{Conclusion}

It is easy to be grim about the lack of breadth and ambition in Australia's contemporary policy debate, when even relatively simple reforms with clear national benefits are unable to progress. 
But there are positive portents the road transport debate will end up heading in good directions, with the transport policy debate already fundamentally changing in the past few years. The motoring clubs are a key reason for this.

The typical role of user groups in a reform debate is to clamour for more investment, greater subsidies and other unreasonable 'solutions'.

When we released our 2014 report, the CEO of the AAA said the association is in favour of road pricing.

The South Australian Labor Premier, Jay Weatherill (2015), said:

I propose that we establish a national heavy vehicle road-user charging system run by the Commonwealth ... South Australia would be willing to trial different elements of heavy vehicle, road user charging.

The then federal assistant minister for infrastructure and regional development, Jamie Briggs (2015), said: '[U]ltimately, road pricing [is] a fairer way for people to ... pay for ... roads, to make sure that they continue to be maintained.'

Business has also begun to respond, with Transurban funding a worldleading technology study, assessing how best to capture usage data and give users choice.

These developments show there is a gathering consensus around this issue, and our principal recommendation is that the federal government should direct the Productivity Commission to establish a detailed public inquiry into the funding, regulation and pricing of Australia's road transport market. This inquiry is necessary to give people a say, but also to explain the trade-offs and the overall benefits of road user pricing.

This is not a niche area of government policy or an abstract application of economic theory; rather, it is a fundamental challenge that is entrenched in the price of the goods and services we consume and produce.

This is a goods and services tax (GST)-level change, affecting every household in the country, but the opportunity for these kinds of discussions to be subverted by cheap fear campaigns and other things has effectively been neutered by the involvement of the major logistics groups and the major motoring organisations. We are simply seeking to begin a genuine, honest and collaborative policy reform process for road user charging and funding. 
Road pricing and road market reform make an exciting discussion for those who work for government central agencies and the transport agencies within government, and they each have a role to play in promoting intelligent debate. It is a discussion that needs to begin and we need to find acceptable solutions.

We need to give governments the complete picture and also give opposition parties the sense that this is a non-partisan issue. This is a policy issue that needs to be 'kicked off' by calm discussion.

It is a very exciting period in road transport reform because we are fresh out of easy answers - and because of the active involvement and support of the motoring clubs.

But the next step is for the federal government to confirm that the issue of road user charging will advance to a full public inquiry.

A detailed public inquiry is needed to 'pull the teeth' on road pricing. It would let the community begin to have a look underneath the bonnet and see what is wrong; and would mean that, in five or 10 years' time, when the road networks are congested and undermaintained to a point where the heat from the community is such that change can happen, we will have a well-debated, well-understood, well-articulated and well-designed system that is able to move forward to implementation.

If a federal inquiry on road pricing happens, I am bullish that road user charging reform will happen in my lifetime.

\section{References}

Briggs, J. (2015). Transcript of speech: Keynote address and luncheon with the Australian British Chamber of Commerce. 9 July. Brisbane. Available from: minister.infrastructure.gov.au/jb/speeches/2015/jbs014_2015.aspx

Department of Infrastructure and Regional Development (DIRD). (2014). Australian Government Response: Productivity Commission Inquiry Report into Public Infrastructure. Canberra: Commonwealth of Australia. Available from: infrastructure.gov.au/infrastructure/publications/files/Productivity Commission_Inquiry_Report_into_Public_Infrastructure.pdf

Industry Commission. (1991). Rail Transport. Volume I: Report. Report No. 13, 21 August. Canberra: Australian Government Publishing Service. 
Infrastructure Partnerships Australia. (2010). Role for Road Pricing in the Australian Context. Discussion paper. Sydney: Infrastructure Partnerships Australia.

Infrastructure Partnerships Australia. (2014). Road Pricing and Transport Infrastructure Funding: Reform Pathways for Australia. Discussion paper. Sydney: Infrastructure Partnerships Australia. Available from: www2.deloitte. $\mathrm{com} /$ content/dam/Deloitte/au/Documents/public-sector/deloitte-au-psroad-pricing-transport-infrastructure-funding-260914.pdf

New South Wales Parliament Legislative Council. (2017). Road tolling in New South Wales. Sydney: Portfolio Committee No. 2 - Health and Community Services. Available from: www.parliament.nsw.gov.au/committees/DBAssets/ InquiryReport/ReportAcrobat/6119/Road\%20Tolling\%20in\%20New $\% 20$ South\%20Wales\%20-\%20Final\%20Report.pdf

Weatherill, J. (2015). South Australia: Essential to the nation's defence. 8 July. National Press Club, Canberra. Available from: www.npc.org.au/speakers/ speaker-2/ 
This text is taken from Road Pricing and Provision: Changed Traffic Conditions Ahead, edited by Michael de Percy and John Wanna, published 2018 by ANU Press, The Australian National University, Canberra, Australia.

doi.org/10.22459/RPP.07.2018.07 